\title{
A Comprehensive Analysis on Technopedagogical Education Competency and Technology Perception of Pre-service Teachers: Relation, Levels and Views ${ }^{1}$
}

\author{
Eylem Yalcin Incik \& Cenk Akay \\ Mersin University, Turkey
}

\begin{abstract}
The main purpose of this research is to identify the competency and the perceptions of pre-service teachers on technopedagogical education. While study group of quantitative dimension is composed of 626 pre-service teachers; study group of qualitative extent is composed of 67 pre-service teachers. The sample represents $35 \%$ of the population of 1778 students. The quantitative data were collected through Technopedagogical Education Competency (Tpack-Deep) Scale and Technology Perception Scale and the qualitative data were collected with an open ended-question form. It was concluded that pre-service teachers generally regard themselves at a moderate level in the sense of technopedogogical education competency, have positive perception towards technology and there is a positive correlation between pre-service teachers' technopedogogical educational competency and perception towards technology. According to results of qualitative analysis of the study, pre-service teachers think that educational technologies have contributions to preparing information-communication technologies based upon presentations, developing technology-based materials, preparing homework, doing research, raising awareness about the importance of educational technology use in the learning and teaching process, acquiring information about their department, developing skill of using technology based on information-communication technologies and having positive attitude.
\end{abstract}

Keywords: Educational technology; Technopedagogical education competency; Information technology; Pre-service teacher; Teaching and learning

\section{Introduction}

Globalization and technological advances experienced towards the end of $20^{\text {th }}$ century caused emergence of new values and trends in social, political, economic and cultural fields. Especially as a result of technological improvements, access to information continued incrementally, a new period started in which nature, function and purposes of education systems are reviewed or altered and technology integration was enabled in education. The integration of technology can be viewed as a transformational process (Kurt, 2012). The belief that technology can positively impact student learning has led many governments to create programs for the integration of technology in their schools (Hew \& Brush, 2007). The effective integration of technology into the educational system is a complex, multifaceted process that involves not just technology but also curriculum and pedagogy, institutional readiness, teacher competencies, and long-term financing, among others (Tinio, 2003). Educational environments

${ }^{1}$ This paper was presented at the $2^{\text {nd }}$ International Eurasian Educational Research Congress in Ankara (Turkey), June 08-10, 2015. 
have witnessed the widening gap between relatively digital immigrant teachers and digital native students (McClure, 2011).

The preparation of teachers in the educational use of technology appears to be a key component in almost every improvement plan for education and educational reform programs (Davis \& Falba, 2002; Dawson, Pringle, \& Adams, 2003; Thompson, Schmidt, \& Davis, 2003). However, at the same time, government policies and initiatives have encouraged teachers to engage with their students' digital worlds (Honan, 2008). It is obvious that, for these reforms to be successful, teachers need to have the necessary knowledge and skills to integrate ICT in classroom learning with focus towards facilitating students' knowledge (Chai, Koh \& Tsai, 2011, p. 595). That is because effective teaching certainly requires effective technology use (Ertmer \& Ottenbreit-Leftwich, 2010).

In the studies carried out for technology use of teachers, it is possible to see the criticisms that teachers use technology restrictedly and in specific periods. The periods in which technology is used by teachers are for information transmission, instructional preparation, communication and for non-educational purposes such as administrative purposes, instructional preparation, teacher-directed instructional delivery, student assignments and instructional assessment rather than the facilitation of students' knowledge construction (Cuban, 2001; Gao, Choy, Wong, \& Wu, 2009; Harris, Mishra, \& Koehler, 2009; Kurt, 2012; McCannon \& Crews, 2000; Ottenbreit-Leftwich, Glazewski, Newby, \& Ertmer, 2010; Sang, Valcke, van Braak, \& Tondeur, 2010; Seferoglu \& Akbiyik, 2005).

It is emphasized in many studies in the literature that the main hindrances against technology use of teachers in education process are arising from lack of information, skill, experience and competency for technology; lack of current pedagogical content knowledge to support learning of students and lack of knowledge about combining technology and negative attitude and lack of motivation (Bingimlas, 2009; Chen, Looi, \& Chen, 2009; Dwyer, Ringstaff \& Sandholtz, 1991; Ertmer et al. 1999; Hew \& Brush, 2007; Honan, 2008; Hutchison \& Reinking 2011; Lim \& Khine, 2006; Lim, 2007; Liu \& Szabo 2009; Oncu, Delialioglu \& Brown, 2008; Zhao, 2007). According to Bhattacherjee and Premkumar (2004), people's beliefs, attitudes, intentions and their use of information technology innovations change over time as they experience technology first hand. These observations have led to more emphasis on teaching teachers' ways of integrating technology in teaching (Angeli \& Valanides, 2009; Goktas, Yildirim, \& Yildirim, 2009; Polly \& Brantley-Dias, 2009). Ertmer et al. (2001) propose that teacher educators have a responsibility to create opportunities in which pre-service teachers can increase their competence and confidence in technology integration. In order to facilitate teacher development for better integration of technology, teacher educators propose that teacher education should move away from technocentric approach to emphasize pedagogy and content (Harris et al., 2009). In view of recognizing the lack of theoretical frameworks to guide teacher preparation in technology integration, researchers, for the last ten years, have initiated systematic research for the purpose of developing theory and models to ground research in the area of teacher cognition about technology integration (Angeli, 2005; Angeli \& Valanides, 2005; Mishra \& Koehler, 2006; Niess, 2005; Valanides \& Angeli, 2008).

TPACK (technological, pedagogical and content knowledge) goes beyond technocentric strategies and emphasizes the importance of helping teachers develop and apply integrated and interdependent understandings of technology, pedagogy, content, and context by describing the different types of technology integration knowledge teachers needed (Angeli \& Valanides 2009; Mishra \& Koehler 2006). TPACK 'connects technology to curriculum content 
and specific pedagogical approaches, and describes how teachers' understandings of these three knowledge bases can interact with one another to produce effective discipline-based teaching with educational technologies (Shin et al., 2009). Niess (2008) defines TPACK as the "body of knowledge that teachers now need for teaching with and about technology in their assigned subject areas and grade levels" (p. 224).

In teachers' competency report of Turkish Education Association (TED) published in 2009, TPACK (p.174) is defined as "having knowledge about curriculum and subject area, the way of teaching program and relation of the field with other fields, tools and structures, integration of the content to be taught in technology" and it was stated that both pre-service and in-service teachers should have this capability. Polly and Brantley-Dias (2009) point out that effective technology integration is the core of TPACK. Finger et al. (2010) state that "We need to encourage the implementation of strategies to better prepare future teachers for learning and teaching in the $21^{\text {st }}$ century. To achieve this, we believe that we need a better, shared understanding of TPACK to inform teacher education courses and programs, to measure preservice teacher education students' TPACK capabilities throughout their program of study."

FATIH (Movement of Enhancing Opportunities and Improving Technology) Project was initiated by the Ministry of National Education in Turkey in 2010. It is aimed with this project to present equality of opportunity in education and improve the technology at schools by providing preschool, primary and secondary schools with laptops, LCD panels, interactive boards and internet which are for effective use of ICT tools in courses. However, it is not sufficient to equip schools with only technology. Integration of technology into learning-teaching process is a complex process and teachers are required to have certain kinds of qualifications and proficiencies. Therefore, it is quite important to carry out studies which analyze teacher education process in the sense of technopedagogical education, and determine perception of pre-service teachers about technology, views of them about education technologies and competence level of them about technopedagogical education. The significance of the study relates to the need for future teachers to have the TPACK capabilities which enable them to enhance and transform learning and teaching by having the necessary technological, pedagogical and content knowledge. On the other hand, Voogt \& McKenney (2017) imply that empowering teachers for effective technology integration does not mean that they need to know the TPACK framework as such but implies that teachers need to understand how to shape instructional practices in which technological, content and pedagogical knowledge are embedded.

Depending on this requirement and importance, the aim of the current study is to analyze competence level of pre-service teachers about technopedagogical education, present the relation with their technological perception and determine their views about educational technologies. Toward to this aim, research questions are:

1. What is the competency level of pre-service teachers about technopedagogical education?

2. What are technological perceptions of pre-service teachers?

3. Do the competence levels and technological perceptions of pre-service teachers about technopedagogical education differ according to variables of gender, class level and program being taught?

4. Is there a relationship between competence level of pre-service teachers about technopedagogical education and their technological perceptions? 
5. What are the views of pre-service teachers about contributions of educational technologies to education processes?

6. What are the suggestions of pre-service teachers for improving contributions of education technologies to education processes?

\section{Methodology}

\section{Research Model}

In this study, the researchers employed both quantitative and qualitative research approaches in the data collection and data analysis processes. Two questionnaires were applied for the quantitative data collection from the pre-service teachers. Open-ended questions were used for the qualitative data collection from the pre-service teachers. By using different approaches, the researchers intended to strengthen the validity of the results. As Creswell (2003) defines, the researcher bases the inquiry on the assumption that collecting diverse types of data best provides an understanding of a research problem in the mixed method. The study begins with a broad survey in order to generalize results to a population and then focuses, in a second phase, on detailed qualitative, open-ended interviews to collect detailed views from the participants.

\section{Participants}

While study group of quantitative dimension of study is composed of 626 pre-service teachers who were having training in the Faculty of Education at Mersin University; study group of qualitative extent is composed of 67 pre-service teachers who are also included in quantitative dimension. Population of the research is comprised of 1778 students and the sample represents $35 \%$ of it. $395(63 \%)$ of pre-service teachers are females while 231 of them (37\%) are males. 150 (24\%) of pre-service teachers study at Turkish Language Teaching, 139 (22\%) at Elementary School Teaching, $123(20 \%)$ at Pre-school Teaching, 80 (13\%) at English Language Teaching, $68(11 \%)$ at Science Teaching and $66(11 \%)$ at Mathematics Teaching.

The prospective teachers had the opportunity to take School Experience and Teaching Practice courses at schools where FATIH project is carried out. In Teaching Practice course, the ones of $4^{\text {th }}$ grade also experienced microteaching practices which enable them to combine content and pedagogy in real class environment. Therefore, grade variable was included in analysis as it was predicted that there would be a difference in competency and perceptions of $4^{\text {th }}$ grade pre-service teachers who experienced teaching practice and $3^{\text {rd }}$ grade ones who did not. Moreover, the department was involved in the research as an independent variable since each department has distinct learning and teaching processes and benefits from the technology differently.

While $150(82 \%)$ of pre-service teachers have a personal computer, $116(19 \%)$ of them do not have a computer. Frequency and percentage distributions about views of pre-service teachers about computer programs to be used in their future occupational life and their competency level are given in Table 1. 
Table 1. Frequency and Percentage Distribution about Views of Pre-Service Teachers about Computer Programs to Be Used in Their Future Occupational Life and Their Competency Level

\begin{tabular}{lcccccc}
\hline & \multicolumn{3}{c}{ Poor } & \multicolumn{2}{c}{ Moderate } & \multicolumn{2}{c}{ Good } \\
\cline { 2 - 7 } & $f$ & $\%$ & $f$ & $\%$ & $f$ & $\%$ \\
\cline { 2 - 7 } Basic terms about computer & 24 & 3,8 & 271 & 43,3 & 331 & 52,9 \\
Hardware & 165 & 26,4 & 316 & 50,5 & 145 & 23,2 \\
Operating system & 86 & 13,7 & 317 & 50,6 & 223 & 35,6 \\
Word processor programs & 38 & 6,1 & 211 & 33,7 & 377 & 60,2 \\
Calculation table programs & 156 & 24,9 & 301 & 48,1 & 169 & 27 \\
Presentation programs & 27 & 4,3 & 180 & 28,8 & 419 & 66,9 \\
\hline
\end{tabular}

When Table 1 is examined, it is seen that, in theme of basic terms on computer, 24 (4\%) of preservice teachers are at poor level, $271(43 \%)$ at moderate level and $331(53 \%)$ at good level. In hardware theme, $165(26 \%)$ of pre-service teachers are at poor level, $316(51 \%)$ at moderate level and 145 (23\%) at good level. In operating system theme, $86(14 \%)$ of pre-service teachers are at poor level, $317(51 \%)$ at moderate level and $223(36 \%)$ at good level. In word processor programs theme, $38(6 \%)$ of pre-service teachers are at poor level, $211(34 \%)$ at moderate level and $377(60 \%)$ at good level. In calculation table programs theme, $156(25 \%)$ of preservice teachers are at poor level, $301(48 \%)$ at moderate level and $169(27 \%)$ at good level. In presentation programs theme, $27(4 \%)$ of pre-service teachers are at poor level, $180(29 \%)$ at moderate level and $419(67 \%)$ at good level. When the table is analyzed in general, it can be said that the field in which pre-service teachers regard themselves competent at good level is presentation programs, the field in which they regard themselves weak is hardware.

\section{Data Collection}

Technopedagogical Education Competency (TPACK-Deep) Scale which was developed by Kabakci Yurdakul et al. (2012) is comprised of 33 items using a 5-point Likert scale, ranging from "strongly disagree $=1$ to strongly agree $=5$. Cronbach alpha coefficient of the scale is 0.95 . In this study, Cronbach alpha coefficient was found 0.96. The lowest score obtained from scale is 33 , the highest score is 165 . Depending on scores obtained from highest and lowest $27 \%$ of groups, if the total scale score of the participant is $\leq 95$, technopedagogical competency of the participant is considered to be at low level; if between 95 and 130, at a moderate level; and if more than 130, at an advanced level.

Technology Perception Scale: Technology Perception Scale, which was developed by Tinmaz (2004), is a 5-point Likert-type scale with 28 items. According to validity and reliability study carried out by Tinmaz (2004), internal consistency coefficient of the whole scale is 0.86 . Cronbach alpha coefficient was found to be 0.93 in this study.

Open-Ended Question Form: There are two open-ended questions in the form which was developed by the researchers. These were; "Explain the effect of instructional technology on your education throughout Faculty of Education" and "What are your suggestions to improve contributions of instructional technologies to the education of pre-service teachers?" Openended question form was presented to 5 academicians who are experts in the field of curriculum and instruction. Experts evaluated data collection tool in the sense of fitness for 
purpose, comprehensibility of the instructions, content and way of answering. Necessary revisions were made based on the feedback obtained from the field experts.

\section{Data Analysis}

Within the general aim of study, SPSS (Statistical Packet for Social Sciences) program was used for statistical analysis of survey forms, demographic variables were interpreted with frequency (f) and percentage (\%) methods which are of descriptive statistics. Competency level of preservice teachers about technopedagogical education and technological perception were interpreted through mean (M), standard deviation (SD), minimum (min) and maximum (max) scores. t-test was used to determine the relationship between gender and class of pre-service teachers and technopedogogical competence level and their technological perception; oneway analysis of variance (ANOVA) was used to determine whether it differs according to department. Pearson correlation analysis was done to determine the level of relationship between competence level of pre-service teachers about technopedogogical education and their technological perception.

Participants who compose study group in analysis of qualitative data were stated with capital letters of "pre-service teacher" and their sequence number (eg: PT1, PT2, PT3); in the analysis of data, content analysis was used which is one of qualitative data analyses. The main purpose in the content analysis is to assess terms and relationships that would explain collected data. The process carried out in content analysis is to gather similar data within the frame of specific terms and themes, to arrange and interpret them in a way that reader would understand (Yildirim \& Simsek, 2008, p.227).

Data obtained from open-ended question form was analyzed in four stages which are (1) codification of data, (2) finding themes, (3) arrangement of codes and themes and (4) identification and interpretation of findings (Yildirim \& Simsek, 2008, p.228). Answers given to open-ended survey questions by pre-service teachers were coded and arranged separately by both researchers. Coded data were analyzed and grouped according to their difference and similarity, codes which are related with each other were gathered and they formed the themes. In this process, codes which have agreement and disagreement were calculated according to Miles and Huberman (1994) reliability formula. Agreement percentages were 0.85 for the first question and 0.83 for the second question. According to Miles Huberman formula, if the percentage is greater than 0.70 , it means that there is an agreement between views of both researchers in the codification and the codification process is reliable. According to values obtained as a result of practice of formula for both questions, codifications are reliable.

\section{Findings}

The first sub-problem of the study was stated as "What is the competency level of pre-service teachers about technopedogogical education?" In order to find an answer for this question; mean (M), standard deviation (SD), minimum (min) score and maximum (max) scores were calculated, and the results were presented in Table 2. 
Table 2. Descriptive Statistics of Pre-Service Teachers about Scores Obtained From Technopedagogical Education Competency (Tpack-Deep) Scale

\begin{tabular}{llccccc}
\hline \multirow{2}{*}{ The whole group } & & $\mathrm{n}$ & $\mathrm{M}$ & $\mathrm{SD}$ & Min & Max \\
\cline { 3 - 6 } Gender & & 626 & 129 & 17,73 & 49 & 165 \\
& Male & 231 & 130,51 & 19,03 & 49 & 165 \\
& Female & 395 & 128,76 & 16,92 & 59,87 & 165 \\
\hline \multirow{2}{*}{ Class } & 3. class & 300 & 129,33 & 16,08 & 72 & 165 \\
& 4. class & 326 & 129,47 & 19,16 & 49 & 65 \\
\hline \multirow{5}{*}{ Department } & 150 & 127,43 & 18 & 58 & 65 \\
& Turkish Teac. & 139 & 128,39 & 16,97 & 90 & 165 \\
& Elt. School Teach. & 123 & 128,02 & 19,94 & 59,87 & 165 \\
& Pre-school Teac. & 80 & 139,40 & 14,05 & 105 & 165 \\
& English Teach. & 68 & 129,47 & 18,22 & 49 & 165 \\
& Science Teach. & 66 & 126,38 & 13,96 & 90 & 165 \\
\hline
\end{tabular}

When descriptive statistics in Table 2 are analyzed; it is seen that the highest score of preservice teachers is 165 , the lowest score is $M=49$ and the mean score is $M=129$. When it is thought that getting score of $\mathrm{M}=130$ and below in the scale refers to moderate level in technopedagogical education competency, it can be said that pre-service teachers regard themselves at a moderate level. Considering gender, it can be said that competency level of male pre-service teachers is at advanced level while that of female pre-service teachers is at moderate level. It is seen in terms of class variable that mean scores of pre-service teachers are so close to each other. Regarding departments variable; it is seen that English Language Teaching Department has the highest mean and Mathematics Teaching Department has the lowest mean.

The second sub-problem of the study was stated as "How is technological perception of preservice teachers?" In order to seek answer for this question; mean (M), standard deviation $(\mathrm{SD})$, minimum $(\mathrm{min})$ score and maximum $(\max )$ score were calculated and results were presented in Table 3.

Table 3. Descriptive Statistics of Pre-Service Teachers about Scores Obtained From Technology Perception Scale

\begin{tabular}{|c|c|c|c|c|c|c|}
\hline & & $\mathrm{n}$ & M & SD & Min & Max \\
\hline \multicolumn{2}{|c|}{ The Whole Group } & 626 & 111,78 & 14,44 & 42 & 140 \\
\hline \multirow[t]{2}{*}{ Gender } & Male & 231 & 112,65 & 15,25 & 42 & 140 \\
\hline & Female & 395 & 111,27 & 13,94 & 42 & 140 \\
\hline \multirow[t]{4}{*}{ Class } & 3. class & 300 & 112,49 & 13,58 & 42 & 140 \\
\hline & 4. class & 326 & 111,12 & 15,18 & 42 & 140 \\
\hline & Turkish Teach. & 150 & 109,45 & 15,97 & 42 & 140 \\
\hline & School Teach. & 139 & 111,44 & 12,97 & 58 & 140 \\
\hline \multirow{4}{*}{ Department } & Pre-school Teach. & 123 & 112,14 & 15,96 & 60 & 140 \\
\hline & English Teach. & 80 & 120,40 & 9,27 & 99 & 140 \\
\hline & Science Teach. & 68 & 111,30 & 13,96 & 56 & 140 \\
\hline & Math.Teach. & 66 & 107,15 & 12,39 & 66 & 136 \\
\hline
\end{tabular}

When descriptive statistics in Table 3 are analyzed, it is seen that the highest score of preservice teachers is 140 and the mean score is $M=111,78$. Considering gender, it can be said 
that the mean of male pre-service teachers $(M=112,65)$ and female pre-service teachers $(M=111,27)$ are very close to each other. According to class variable; mean scores of preservice teachers who have education at $3^{\text {rd }}$ class $(M=112,49)$ and $4^{\text {th }}$ class $(M=111,12)$ are very close to each other. Regarding departments; it is seen that English Language Teaching Department has the highest mean $(M=120,40)$ and Mathematics Teaching Department has the lowest mean $(M=107,15)$.

The third sub-problem of study was stated as "Do the competence levels and technological perceptions of pre-service teachers about technopedagogical education differ according to variables of gender, class level, program being taught?" In order to seek answer for this question; independent samples t-test was used to determine whether competence level of pre-service teachers on technopedogogical education and perception scores on technology differ according to gender and class level variables; one-way ANOVA statistics was used in order to determine whether they differ according to program being taught. The results are presented in Table 4 and 5.

Table 4. Independent Samples t-Test Results

\begin{tabular}{|c|c|c|c|c|c|c|c|}
\hline \multirow{6}{*}{$\begin{array}{l}\text { Competence } \\
\text { about Techno- } \\
\text { pedagogical } \\
\text { Education }\end{array}$} & Gender & $\mathrm{n}$ & $\mathrm{M}$ & SS & SD & $\mathrm{t}$ & $p$ \\
\hline & Male & 231 & 130,51 & 19,03 & \multirow{2}{*}{624} & \multirow{2}{*}{1,19} & \multirow{2}{*}{0,233} \\
\hline & Female & 395 & 128,76 & 16,9 & & & \\
\hline & Class Level & $n$ & Mean & ss & SD & $\mathrm{t}$ & $p$ \\
\hline & 3. Class & 300 & 129,33 & 16,08 & \multirow{2}{*}{624} & \multirow{2}{*}{0,10} & \multirow{2}{*}{0,917} \\
\hline & 4. Class & 326 & 129,47 & 19,16 & & & \\
\hline \multirow{6}{*}{$\begin{array}{l}\text { Perception about } \\
\text { Technology }\end{array}$} & Gender & $\mathrm{n}$ & Mean & SS & SD & $t$ & $p$ \\
\hline & Male & 231 & 112,65 & 15,25 & \multirow{2}{*}{624} & \multirow{2}{*}{1,15} & \multirow{2}{*}{0,259} \\
\hline & Female & 395 & 111,27 & 13,94 & & & \\
\hline & Class Level & $\mathrm{n}$ & Mean & SS & SD & $\mathrm{t}$ & $p$ \\
\hline & 3. Class & 300 & 112,49 & 13,58 & \multirow{2}{*}{624} & \multirow{2}{*}{1,19} & \multirow{2}{*}{0,235} \\
\hline & 4. Class & 326 & 111,12 & 15,18 & & & \\
\hline
\end{tabular}

According to the analyses in Table 4, it is seen that there is no significant difference between the means of competence level index of pre-service teachers about technopedogogical education in terms of gender $\left(t_{\text {tpack }}=1,19 ; p>0.05\right)$ and class level $\left(t_{\text {tpack }}=0,10 ; p>0.05\right)$. When descriptive statistics are analyzed with regard to their perception about technology, there is no significant difference between means of perception index of pre-service teachers about technology according to gender $\left(t_{\text {tpack }}=1,15 ; p>0.05\right)$ and class level $\left(t_{\text {tpack }}=0,19 ; p>0.05\right)$.

Table 5. ANOVA Results about Pre-Service Teachers' Score Means of Competency Level about Technological Education According to Variable of Program Being Taught

\begin{tabular}{|c|c|c|c|c|c|c|c|}
\hline \multirow{4}{*}{$\begin{array}{l}\text { Competence } \\
\text { about } \\
\text { Techno } \\
\text { pedagogical } \\
\text { Education }\end{array}$} & $\begin{array}{l}\text { Source of } \\
\text { Variance }\end{array}$ & $\begin{array}{l}\text { Sum of } \\
\text { Squares }\end{array}$ & SD & $\begin{array}{l}\text { Mean of } \\
\text { Squares }\end{array}$ & $\mathrm{F}$ & $p$ & Differences \\
\hline & Intergroup & 9559,057 & 5 & 1911,811 & \multirow{3}{*}{6,334} & \multirow{3}{*}{0.000} & Eng.T>T.T; \\
\hline & Intragroup & 187121,914 & 620 & 301,810 & & & M.T.; S.T; \\
\hline & Total & 196680,71 & 625 & & & & P-S.T.; Sci.T. \\
\hline \multirow{3}{*}{$\begin{array}{l}\text { Department } \\
\text { Means }\end{array}$} & English & Turkish & \multirow{2}{*}{\multicolumn{2}{|c|}{$\begin{array}{l}\text { Elementary } \\
\text { Math. Teach. }\end{array}$}} & School & Preschool & Science \\
\hline & Teaching & Teaching & & & Teaching & Teach. & Teaching \\
\hline & 139,40 & 127,43 & \multicolumn{2}{|c|}{126,38} & 128,39 & 128,02 & 129,47 \\
\hline
\end{tabular}




\begin{tabular}{|c|c|c|c|c|c|c|c|}
\hline \multirow{4}{*}{$\begin{array}{l}\text { Perception } \\
\text { about } \\
\text { Technology }\end{array}$} & $\begin{array}{c}\text { Resource of } \\
\text { Variance }\end{array}$ & $\begin{array}{l}\text { Sum of } \\
\text { Squares }\end{array}$ & SD & $\begin{array}{l}\text { Mean of } \\
\text { Squares }\end{array}$ & $\mathrm{F}$ & $P$ & Differences \\
\hline & Intergroup & 8230,603 & 5 & 1646,121 & & & Eng.T>T.T; \\
\hline & Intragroup & 122185,240 & 620 & 197,073 & 8,353 & 0.000 & M.T.; S.T; \\
\hline & Total & 130415,842 & 625 & & & & P-S.T.; S.T. \\
\hline \multirow{2}{*}{$\begin{array}{l}\text { Department } \\
\text { Means }\end{array}$} & $\begin{array}{c}\text { English } \\
\text { Teaching }\end{array}$ & $\begin{array}{l}\text { Turkish } \\
\text { Teaching }\end{array}$ & \multicolumn{2}{|c|}{$\begin{array}{l}\text { Elementary } \\
\text { Math. Teach. }\end{array}$} & $\begin{array}{c}\text { School } \\
\text { Teaching }\end{array}$ & $\begin{array}{c}\text { Preschool } \\
\text { Teach. }\end{array}$ & $\begin{array}{c}\text { Science } \\
\text { Teaching }\end{array}$ \\
\hline & 120,40 & 109,45 & \multicolumn{2}{|c|}{107,15} & 111,44 & 112,14 & 111,30 \\
\hline
\end{tabular}

Considering the analyses in Table 5, it is seen that there is a significant difference between mean scores of pre-service teachers' competency level about technopedagogical education according to department variable $\left(F_{(5-620)}=6,334, p<.01\right)$. In other words, pre-service teachers' competency level about technopedogogical education differs significantly according to their departments. According to the results of Scheffe test which was carried out to determine between which departments there are differences, it was found that competency level $(M=139,40)$ of pre-service teachers who continue their education at English Language Teaching Department is higher than those who receive education at Turkish Language Teaching $(M=127,43)$, Elementary Mathematics Teaching $(M=126,38)$, Elementary School Teaching $(M=128,39)$, Preschool Teaching $(M=128,02)$ and Science Teaching $(M=129,47)$ departments.

Regarding the analyses in Table 5, it is seen that there is significant difference between mean scores of pre-service teachers' perception about technology according to department variable $\left(F_{(5-620)}=8,353, p<.01\right)$. In other words, pre-service teachers' perception about technology differs significantly according to their departments. According to the results of Scheffe test which was carried out to determine between which departments there are differences, it was found that competency level $(M=120,40)$ of pre-service teachers who have education at English Language Teaching Department is higher than those who receive education at Turkish Language Teaching $(M=109,45)$, Elementary Mathematics Teaching $(M=107,15)$, Elementary School Teaching $(M=111,44)$, Preschool Teaching $(M=112,14)$ and Science Teaching $(M=111,30)$ departments.

The fourth sub-problem of the study is stated as "Is there a relation between competence level of pre-service teachers about technopedagogical education and their technological perceptions?" In order to seek answer for this question, the relationship between competence level of pre-service teachers about technopedagogical education and their technological perceptions was analyzed with Pearson Correlation coefficient and the findings are presented in Table 6.

Table 6. Pearson Correlation Coefficient between Competence Level of Pre-Service Teachers about Technopedagogical Education and Their Technological Perceptions

\begin{tabular}{lcc}
\hline & $\mathrm{p}$ & $\mathrm{p}$ \\
\hline Competence about Technopedogogical Education &, 584 &, 000 \\
Perception about Technology &, \\
\hline
\end{tabular}

Taking the analyses in Table 6 into account, it is seen that there is a significant relation in positive direction between competence level of pre-service teachers about technopedagogical education and their technological perceptions $(r=0.584, p<0.01)$. According to this, it can be said that as competence level of pre-service teachers about technopedagogical education increases, so does their perception about technology. 
The fifth sub-problem of the study is stated as "What are the views of pre-service teachers about contributions of educational technologies to education processes?" In order to seek answer for this question, answers of pre-service teachers given for open-ended questions were analyzed with content analysis.

When descriptive analyses are examined, it is seen that answers of pre-service teachers gather under four main themes which are contribution to educational status, contribution to occupational improvement, contribution to active use of technology and no contribution. For pre-service teachers, the most common points about contribution of educational technologies to education processes are preparing information-communication technologies (ICT)-based presentations $(f=12)$ and developing technology-based materials $(f=7)$ in the sense of education status, raising awareness about importance of educational technology use in learning-teaching process ( $f=13)$, having information about department $(f=4)$, developing activities based on in-class visuals (4) in terms of contribution to occupational development, using practices based on information-communication technologies $(f=23)$ and developing skill of using technology $(f=6)$ in the sense of effective use of technology. For this question, some of the pre-service teachers stated their views as that educational technologies have no contribution to education processes $(f=7)$ and few teachers stated that technology is not used satisfactorily $(\mathrm{f}=2)$. Some of the pre-service teachers' views about this question are as such:

"I think it enables me to be raised as more qualified teacher. Computer-based education especially in mathematics teaching would enable both teachers to be more efficient in the field and students to receive better education." (PT2)

"In my occupation as a teacher, I will be able to make use of technology (educational technologies) to provide more efficient learning in shorter time for students. I think educational technologies will be beneficial first of all for this reason. Throughout my education, I could use educational technologies effectively while making homework and preparing projects. In the presentation I have made contribution by using educational listening, postcards, and PowerPoint presentations." (PT31)

The sixth sub-problem of study is stated as "What are the suggestions of pre-service teachers for improving contributions of education technologies to education processes?" In order to seek answer for this question, answers of pre-service teachers given for open-ended questions were analyzed with content analysis.

When descriptive statistics are taken into consideration, it is seen that the answers of preservice teachers gather under two themes, namely: enhancement of physical infrastructure and teaching educational technologies. Under the theme of teaching educational technologies, pre-service teachers stated that educational technologies should be practice-centered $(f=14)$, more time should be spared for teaching educational technologies $(f=11)$, developments in educational technologies should be followed more closely $(f=5)$ and technology-based content in subject fields should be increased $(f=4)$. Under the theme of enhancement of physical infrastructure, they stated that the number of computers in the university should be increased $(f=5)$, technological equipment should be increased $(f=4)$ and up-to-date technological equipment should be used $(f=3)$. The views of some of the teachers for this question are as such:

"There should be more computer courses. Pre-service teachers can be asked for developing various projects. The importance of technology can be emphasized through conferences and seminars." (PT62) 
"Pre-service teachers should be given information technology courses from the very beginning. Teaching period should not be restricted with limited time and the course should be taught in a permanent way. Practice should be made profoundly." (PT33)

"I think there should be more space for technological software and hardware use within the content of courses. Moreover, I believe not being able to exceed standard and common programs hebetates available potential and tendency. Program usage as taught in the courses is very superficially explained and students use software without being aware of their potential power. They cannot show more advanced performance. This is a basic problem to be solved." (PT32)

\section{Conclusion and Discussion}

In this study, pre-service teachers' who are at the $3^{\text {rd }}$ and $4^{\text {th }}$ year of the Faculty of Education, competency level about technopedogogical education and their technological perception were analyzed according to gender, department and class; the relationship between competency level about technopedogogical education and technological perception and the views of preservice teachers about education technologies were also analyzed, and the findings were discussed below. It was concluded that pre-service teachers generally regard themselves at moderate level in the sense of technopedogogical education competency. Findings of the study show that pre-service teachers have positive perception towards technology. It can be said that findings obtained from the study are parallel with the findings in the literature that pre-service teachers have positive views about the effective use of technology and integrating technology into their education (Choy, Wong \& Gao, 2009; Gulbahar, 2008). In addition, according to the research that Gill and Dalgarno (2017) conducted in depth with 6 Australian pre-service teachers, a range of aspects of university preparation including ICT skill and pedagogy subject, assignments and lecturer modelling also had a clear effect on the growth of the pre-service teachers' TPACK.

The findings of the current study show that pre-service teachers' competency level about technopedogogical education and their technological perception do not differ according to gender and department. This result can be interpreted as that gender and class level variables are not factors that affect technopedogogical educational competency and perception towards technology. When similar studies in the literature are analyzed, it is seen that there are results parallel with this study. For example, in the studies carried out by Akgun (2013), Gomleksiz and Fidan (2011), Kazu and Erten (2011), Kaya, Ozdemir, Emre and Kaya (2011); it was concluded that web pedagogical content knowledge of pre-service teachers do not differ according to gender variable. The qualifications expected to be formed within education process are determined without making any discrimination between students and it is expected that all the students should have these qualifications similarly. In the process of teacher education, it is expected that differences such as gender, department and education type etc. should not affect the qualifications to be attained and pre-service teachers should be graduated with similar qualifications. This finding obtained as a result of the study is compatible with the expectations that pre-service teachers should attain self-sufficiency perceptions without any discrimination. Furthermore, the results of the research Scherer et al. (2017) carried out with 665 pre-service teachers at 18 teacher training institutions in Belgium indicated that the measure of the technology-dimensions within the TPACK framework is able to capture preservice teachers' general TPACK self-beliefs and their specific self-beliefs in technological knowledge. 
The findings of this study show that pre-service teachers' technopedogogical educational competency and perception towards technology differ significantly on behalf of pre-service teachers who study at English Language Teaching Department. One of the most important factors which have positive effect on competency perception about the use of information and communication technologies for educational purposes is the utilization of these technologies in course activities. Lawless and Pellegrino stated "technology can make it quicker or easier to teach the same things in routine ways, or it can make it possible to adopt new and arguably better approaches to instruction and/or change the content or context of learning." (2007, p.581). Courses of English Language Teaching have included contents and materials which require intensive use of educational technologies for long years. Education activities of this department necessitate the use of audio-visual materials and the use of technological tools and provide original context and technological infrastructure for pre-service teachers at this department by which they would learn technology through practicing and experiencing. Bhattacherjee and Premkumar (2004) stated that when pre-service teachers have direct experience with technology, their attitude towards technology and their use of technology would change. This may be the reason why both technopedogogical education competency level and technological perception of pre-service teachers who study at English Language Teaching Department are significantly different from other departments.

The findings of the current study show that there is a positively significant relationship between pre-service teachers' technopedogogical educational competency and perception towards technology. According to the literature, perception about competency is one of the important extents of technology integration (Ertmer, Conklin \& Lewandowski 2001; Finger, Jamieson-Proctor \& Albion 2010). This result is parallel with the result of research carried out by Chen (2010) which shows that pre-service teachers' self-sufficiency about technology has a very powerful effect on technology use. This finding also matches up with the result of another study which states that increase of pre-service teachers' technological knowledge and skill also enhances their self-sufficiency about technology integration (Lambert \& Gong, 2010). Ertmer et al. state that if teachers do not believe that they can integrate technology, they may not use it at all.

According to the results of qualitative analysis of the study, pre-service teachers think that educational technologies have contributions to preparing ICT-based presentations, developing technology-based materials, preparing homework, doing research, raising awareness about importance of educational technology use in the learning and teaching process, acquiring information about their department, developing personal skill of using technology based on information-communication technologies and having a positive attitude toward technology in general. Very few of the pre-service teachers think that it has no contribution to education process. Pre-service teachers also think that technological equipment should be maximized, up-to-date technological equipment should be used and teaching of educational technologies should be practice-based in order to improve contribution of educational technologies to instructional processes.

\section{Recommendations}

In light of findings of the current study, the following suggestions have been provided for the practitioners and researchers: 


\section{For Practitioners}

- One of the important steps about integration of information and communication technologies into teacher education is to provide original context and technological infrastructure for pre-service teachers where they can learn through practicing and experiencing. Progress can be achieved about this issue when curriculum of Faculties of Education is enriched with optional courses that help or would enable pre-service teachers' use of technologies based on pedagogy and content knowledge.

- Different courses of teacher training fields can be implemented with technology (IT) assisted approach.

- In order to teach pre-service teachers how to integrate learning environments to technology, practice-oriented activities which include instructional design through technology should be arranged. In this way, pre-service teachers would have more opportunity about technology use for educational purposes and they would have a positive attitude towards technopedogogical education and the use of technology in education.

- It is important to teach courses in each branch about the execution of technology integration in curriculum of Faculties of Education and to give students instructions about how to integrate ICT according to subjects in the classroom.

- It must be paid particular attention in this process that academicians should integrate technology effectively during their courses and be good role-models for prospective teachers. Training seminars can be conducted for academicians about integrating technology and current technology through learning environments.

- Computer laboratories should be open to the use of pre-service teachers apart from courses so that they can use these technologies more frequently.

- In order to construct education environment suitable to technology use in education, the number of students in classes should be reduced from 40-50s to 20s, laboratory and material deficiencies should be overcome, and special classrooms should be designed according to the quality of courses.

- Projects can be developed by which pre-service teachers can make peer-learning about current technologies and have information from each other.

- Technology consulting center can be founded in Faculties of Education in order to provide pre-service teachers with consulting service.

\section{For Researchers}

- It is thought that further research should be done in which different variables that are thought to be effective in perception about technology and technopedogogical education competency are involved and experimental designs are arranged about observation of learning-teaching processes.

- Mixed and longitudinal methods may be employed to examine the technological perceptions of the pre-service teachers.

- Comparative studies may be conducted between the countries which have better rankings in PISA assessments to identify the effectiveness of technology in teacher training. 


\section{References}

Angeli, C. \& Valanides, N. (2005). Pre-service elementary teachers as information and communication technology designers: an instructional systems design model based on an expanded view of pedagogical content knowledge. Journal of Computer Assisted Learning, 21(4), 292-302.

Angeli, C. (2005). Transforming a teacher education method course through technology: effects on pre-service teachers' technology competency. Computers and Education, 45(4), 383-398.

Akgun, F. (2013). Pre-service teachers' web pedagogical content knowledge and relationship between teachers' perception of self-efficacy. Trakya University Journal of Education 3(1), 48-58.

Bhattacherjee, A. \& Premkumar, G. (2004). Understanding changes in belief and attitude toward information technology usage: A theoretical model and longitudinal test. MIS Quarterly, 28(2) 229-254.

Bingimlas, K. (2009). Barriers to the successful integration of ICT in teaching and learning environments: A review of the literature. Eurasia Journal of Mathematics, Science \& Technology Education, 5(3), 235-245.

Chai, C.S., Koh, J. H., \& Tsai, C. (2011). Exploring the factor structure of the constructs of technological, pedagogical, content knowledge (TPAC). The Asia-Pacific Education Researcher, 20(3), 595-603.

Chen, R. (2010). Investigating models for pre-service teachers' use of technology to support student-centered learning. Computers and Education, 55(1), 32-42.

Chen, F., Looi, C., \& Chen, W. (2009). Integrating technology in the classroom: A visual conceptualization of teachers' knowledge, goals and beliefs. Journal of Computer Assisted Learning, 25(5), 470-488.

Choy, D., Wong, A.F.L., \& Gao, P. (2009). Student teachers' intentions and actions on integrating technology into their classrooms during student teaching: A Singapore study. Journal of Research on Technology in Education, 42(2), 175-195.

Cuban, L. (2001). High access and low use of technologies in high school classrooms: Explaining an apparent paradox. American Educational Research Journal, 38(4), 813-834.

Creswell, J.W. (2003). Research design: Qualitative, quantitative, and mixed method approaches. Thousand Oaks, CA: Sage.

Davis, K.S. \& Falba, C.J. (2002). Integrating technology in elementary pre-service teacher education: orchestrating scientific inquiry in meaningful ways. Journal of Science Teacher Education, 13(4), 303-329.

Dawson, K., Pringle, R., \& Adams, T.L. (2003). Providing links between technology integration, methods courses, and school-based field experiences: a curriculum-based and technology-enhanced microteaching. Journal of Computing in Teacher Education, 20(1), 41-47.

Dwyer, D.C., Ringstaff, C., \& Sandholtz, J.H. (1991). Changes in teachers' beliefs and practices in technology rich classrooms. Educational Leadership, 48(8), 45-52. 
Ertmer, P.A., Addison, P., Lane, M., Ross, E., \& Woods, D. (1999). Examining teachers' beliefs about the role of technology in the elementary classroom. Journal of Research on Computing in Education, 32(1), 54-72.

Ertmer, P.A., Conklin, D., \& Lewandowski, J. (2001). Increasing pre-service teachers' capacity for technology integration through use of electronic models. Paper presented at the Annual Meeting of National Convention of the Association for Educational Communications and Technology. Atlanta, GA.

Ertmer, P.A. \& Otternbreit-Leftwich, A.T. (2010). Teacher technology change: How knowledge, confidence, beliefs, and culture intersect, Journal of Research on Technology in Education, 42(3), 255-284.

Finger, G., Jamieson-Proctor, R., \& Albion, P. (2010). Beyond pedagogical content knowledge: The importance of TPACK for informing pre-service teacher education in Australia. In N. Reynolds, \& M. Turcsanyi-Szabo (Eds.), Key competencies in the knowledge society: Proceedings of IFIP TC 3 International Conference, Volume 324 (pp.114-125). Berlin, Germany: Springer.

Gao, P., Choy, D., Wong, A.F.L. \& Wu, J. (2009). Developing a better understanding of technology-based pedagogy. Australasian Journal of Educational Technology, 25(5), 714730.

Gill, L. \& Dalgarno, B. (2017). A qualitative analysis of pre-service primary school teachers' TPACK development over the four years of their teacher preparation programme. Technology, Pedagogy and Education, (Online), 1-18, doi:10.1080/1475939X.2017. 1287124.

Gomleksiz, M. N. \& Fidan, E. K. (2011). Self-efficacy perception levels of prospective teachers' enrolled at pedagogical formation course toward web pedagogical content knowledge. Turkish Studies-International Periodical for the Languages, Literature and History of Turkish or Turkic, 6(4), 593-620.

Goktas, Y., Yildirim, S., \& Yildirim, Z. (2009). Main barriers and possible enablers of ICT integration into pre-service teacher education programs. Educational Technology \& Society, 12(1), 193-204.

Gulbahar, Y. (2008). Improving the technology integration skills of prospective teachers through practice: A case study. The Turkish Online Journal of Educational Technology, 7(4), 71-81.

Harris, J., Mishra, P., \& Koehler, M. (2009). Teachers' technological pedagogical content knowledge and learning activity types: curriculum-based technology integration reframed. Journal of Research on Technology in Education, 41(4), 393-416.

Hew, K. \& Brush, T. (2007). Integrating technology into K-12 teaching and learning: Current knowledge gaps and recommendations for future research. Educational Technology Research and Development, 55(3), 223-252.

Honan, E. (2008). Barriers to teachers using digital texts in literacy classrooms. Literacy, 42(1), 36-43.

Hutchison, A. \& Reinking, D. (2011). Teachers' perceptions of integrating information and communication technologies into literacy instruction: a national survey in the United States. Reading Research Quarterly, 46(84), 312-333. 
Jordan, K. (2013). The influence of gender on beginning teachers' perceptions of their technological pedagogical content knowledge (TPACK). Australian Educational Computing, 28(2), 32-50.

Kabakci Yurdakul, I., Odabasi, H.F., Kilicer, K, Coklar, A.N., Birinci, G., \& Kurt, A.A. (2012). The development, validity and reliability of TPACK-deep: A technological pedagogical content knowledge scale. Computers and Education, 58(3), 964-977.

Kaya, Z., Ozdemir, T.Y., Emre, I., \& Kaya, O.N. (2011). Exploring pre-service information technology teachers' perception of self-efficacy in web-technological pedagogical content knowledge. $6^{\text {th }}$ International Advanced Technologies Symposium (IATS'11), Elazıg, Turkey.

Kazu, i. Y. \& Erten, P. (2011). The views of elementary pre-service teachers towards web pedagogical content knowledge. $10^{\text {th }}$ National Elementary Teaching Education Symposium. Cumhuriyet University, Sivas, Turkey.

Kurt, S. (2012). Examining teachers' use of computer-based technologies: A case study. Education and Information Technologies, 18(4), 557-570.

Lambert, J. \& Gong, Y. (2010). 21st century paradigms for pre-service teacher technology preparation. Computers in the Schools, 27(1), 54-70.

Lawless, K.A, \& Pellegrino, J.W. (2007). Professional development in integrating technology in to teaching and learning: knowns, unknowns, and ways to pursue better questions and answers. Review of Educational Research, 77(4), 575-614.

Lim, C.P. \& Khine, M. (2006). Managing teachers' barriers to ICT integration in Singapore schools. Journal of Technology and Teacher Education, 14(1), 97-125.

Lim, C.P. (2007). Effective integration of ICT in Singapore schools: Pedagogical and policy implications. Education Technology Research \& Development, 55(1), 83-116.

Liu, Y. \& Szabo, Z. (2009). Teachers' attitudes toward technology integration in schools: A four year study. Teachers and Teaching: Theory and Practice, 15(1), 5-23.

McCannon, M. \& Crews, T.B. (2000). Assessing the technology needs of elementary school teachers. Journal of Technology and Teacher Education, 8(2), 11-121.

McClure, R. (2011). The digital information divide. In S. D'Agustino (Ed.), Adaptation, resistance and access to instructional Technologies: Assessing future trends in education. Hershey, PA: IGI Global Information Science Reference.

Miles, M.B. \& Hubermann, A.M. (1994). Qualitative data analysis. Thousand Oaks, CA: Sage.

Mishra, P. \& Koehler, M.J. (2006). Technological pedagogical content knowledge: A framework for teacher knowledge. Teachers College Record, 108(6), 1017-1054.

Niess, M.L. (2005). Preparing teachers to teach science and mathematics with technology: Developing a technology pedagogical content knowledge. Teaching and Teacher Education, 21(5), 509-523.

Niess, M.L. (2008). Guiding pre-service teachers in developing TPCK. In AACTE (Eds.), Handbook of technological pedagogical content knowledge (TPCK) for educators (pp.223-250). New York: Routledge. 
Oncu, S., Delialioglu, O. \& Brown, C.A. (2008). Critical components for technology integration: How do instructors make decisions? Journal of Computers in Mathematics and Science Teaching, 27(1), 19-46.

Ottenbreit-Leftwich, A.T., Glazewski, K.D., Newby, T.J., \& Ertmer, P.A. (2010). Teacher value beliefs associated with using technology: addressing professional and student needs. Computers and Education, 55(3), 1321-1335.

Polly, D. \& Brantley-Dias, L. (2009). TPACK: Where do we go now? TechTrends, 53(5), 46-47.

Sang, G., Valcke, M., van Braak, J., \& Tondeur, J. (2010). Student teachers' thinking processes and ICT integration: Predictors of prospective teaching behaviors with educational technology. Computers and Education, 54(1), 103-112.

Scherer, R., Tondeur, J. \& Siddiq, F. (2017). On the quest for validity: Testing the factor structure and measurement invariance of the technology-dimensions in the technological, pedagogical, and content knowledge (TPACK) model. Computers \& Education, 112, 1-17.

Seferoglu, S.S. \& Akbiyik, C. (2005). A study on primary school teachers' perceived computer self-efficacy. Eurasian Journal of Educational Research, 19, 89-101.

Shin, T.S., Koehler, M.J., Mishra, P., Schmidt, D.A., Baran, E., \& Thompson, A.D. (2009). Changing technological pedagogical content knowledge (TPACK) through course experiences. In I. Gibson, R. Weber, K. McFerrin, R. Carlsen, \& D. A. Willis (Eds.), Society for information technology and teacher education (pp.4152-4156). Chesapeake, VA: Association for the Advancement of Computing in Education (AACE).

Tinio, V. (2003). ICT in education. ICT for development. New York: United Nations Development Programme.

Tinmaz, H. (2004). An Assessment of Pre-service Teachers' Technology Perception in Relation to Their Subject Area (Unpublished master's thesis). Middle East Technical University. The Graduate School of Social Sciences. Ankara, Turkey.

Thompson, A.D., Schmidt, D.A., \& Davis, N.E. (2003). Technology collaboratives for simultaneous renewal in teacher education. Educational Technology Research and Development, 51(1), 124-128.

TED. (2009). Ogretmen yeterlikleri: Ozet rapor (1. baski). ISBN 978-9944-5128-7-9.

Valanides, N. \& Angeli, C. (2008). Learning and teaching about scientific models with a computer modeling tool. Computers in Human Behavior, 24(2), 220-233.

Yildirim, A. \& Simsek, H. (2008). Qualitative research methods in social sciences. Ankara: Seckin.

Zhao, Y. (2007). Social studies teachers' perspectives of technology integration. Journal of Technology and Teacher Education, 15(3), 311-333.

Correspondence: Cenk Akay, Assistant Professor, Department of Educational Sciences, Division of Curriculum and Instruction, Faculty of Education, Mersin University, Yenisehir Campus, Mersin, Turkey. 